\title{
EFFECTS OF THE EXCHANGE RATE ONINTERNATIONAL PRICES OF PULP AND PAPER IN BRAZILIAN CURRENCY
}

\author{
Naisy Silva Soares ${ }^{1}$, Eliane Pinheiro de Sousa ${ }^{2}$, Márcio Lopes da Silva ${ }^{3}$
}

(received: April 24, 2009; accepted: February 26, 2010)

\begin{abstract}
This study aimed to analyze effects of the exchange rate adopted in Brazil as well as pulp and paper prices in the U.S. on pulp and paper prices in Brazilian currency, from April 2003 to February 2009. To attain that, the shift-share method was used, and analysis results indicated that price variations in Brazilian currency were more strongly influenced by exchange rate variations than by variations in dollar prices, demonstrating the importance of the exchange rate policy adopted by Brazil in the behavior of pulp and paper prices.
\end{abstract}

Key words: Pulp and paper sector, shift-share,price variation.

\section{EFEITOS DA TAXA DE CÂMBIO SOBRE OS PREÇOS INTERNACIONAIS DA CELULOSE E DO PAPEL BRASILEIRO}

RESUMO: Analisou-se, neste estudo, os efeitos da taxa de câmbio adotada pelo Brasil e dos preços da celulose e do papel nos Estados Unidos, sobre os preços da celulose e do papel em moeda brasileira, de abril de 2003 a fevereiro de 2009. Para isso, fez-se uso do método de análise shift-share. Considerando os resultados obtidos, observou-se que as variações ocorridas nos preços, em moeda brasileira, sofreram maior influência das variações da taxa de câmbio, que das variações dos preços em dólar, indicando a importância da política cambial adotada pelo Brasil sobre o comportamento dos preços da celulose e do papel.

Palavras-chave: Segmento de celulose e papel, shift-share,variação de preços.

\section{INTRODUCTION}

The pulp and paper sector has been of crucial importance for the Brazilian economy, opening up new sources of foreign currency, creating jobs, generating taxes and income. According to the Brazilian Pulp and Paper Association-Bracelpa (2008), in 2007 the revenues generated by exports and tax collection in the Brazilian pulp and paper sector totaled around US $\$ 4.7$ billions and $\mathrm{R} \$ 2.1$ billions respectively, and the balance of trade result reached US\$ 3.4 billions. Additionally, the sector generated 110 thousand direct jobs and 500 thousand indirect jobs in that same year in Brazil.

With the U.S. financial crisis looming in the second semester of 2008, the worldwide demand for wood pulp and paper declined considerably. With declining demand, a price slump followed toward the latter part of the year in the U.S. and in other countries, including Brazil (CELULOSE ONLINE 2009, SILVA et al. 2009).

In the period between May 2008 and January 2009, short fiber pulp prices fell by $26 \%$ in São Paulo state, while offset paper prices, roll and A4, fell by $25 \%$ and $30 \%$ respectively. In the same period, long fiber pulp prices slumped by $47 \%$ in the U.S. (FOEX, as cited by CELULOSE ONLINE 2009).

The fall in pulp and paper prices in the international market as observed in past months had negative effects on the forest economy worldwide, including Brazil—ranked sixth in the world for production of pulp all types being considered, first for production of short fiber pulp and eleventh for paper production-, significantly contributing to the current crisis faced by the Brazilian sector.

Given that international pulp and paper price in Brazilian currency is derived by multiplying the international price in U.S. dollar by the real exchange rate adopted by Brazil (R $\$ / U S \$)$, any variation in these factors, isolated or combined, potentially affects domestic prices.

Following the above line of reasoning, it can be inferred that the exchange rate adopted in Brazil has great importance in defining internal pulp and paper prices, due to their dependence on prices practiced by the U.S.

\footnotetext{
${ }^{1}$ Economist, PhD candidate in Forest Science - Departamento de Engenharia Florestal/DEF - Universidade Federal de Viçosa/UFV Avenida Peter Henry Rolfs, s/n - Campus Universitário - 36570-000 - Viçosa, MG - naisysilva@yahoo.com.br

${ }^{2}$ Economist, PhD candidate in Applied Economics - Departamento de Economia Rural/DER - Universidade Federal de Viçosa/UFV Avenida Peter Henry Rolfs, s/n - Campus Universitário - 36570-000 - Viçosa, MG - pinheiroeliane@ hotmail.com ${ }^{3}$ Forest Engineer, Professor, PhD in Forest Economics - Departamento de Engenharia Florestal/DEF - Universidade Federal de Viçosa/UFV Avenida Peter Henry Rolfs, s/n - Campus Universitário - 36570-000 - Viçosa, MG - marlosil@ufv.br
} 
Therefore, the objective of this work is to investigate the effects of the exchange rate adopted in Brazil on international prices of pulp and paper expressed in Brazilian currency, and the consequences of that for the internal market.

The need for related research becomes critical to supply new information on which to base efficient planning of production, commercialization, prognosis and formulation of policies for the development of the Brazilian forest sector.

\section{MATERIAL AND METHODS}

\subsection{Data source}

Monthly time series data were used from the period between April 2003 and February 2009.

Pulp prices in the international market refer to short fiber pulp prices in the U.S. Paper prices refer to newsprint prices, also in the U.S. The reason for using pulp and paper prices practiced in the U.S. is that prices practiced on these products by Brazil at international level are believed to be influenced by U.S. prices, the country being the largest producer and also a major exporter and consumer of these products, according to the Food and Agriculture Organization-FAO (2009).

Pulp and paper prices in the U.S. are provided by FOEX Index Ltd. and were obtained from CELULOSE ONLINE (CELULOSE ONLINE 2009), and refer to prices in US\$ per ton.

The nominal exchange rate of Brazil (R\$/US\$) is provided by the Central Bank of Brazil and was obtained from the Institute of Applied Economic Research (INSTITUTO DE PESQUISA ECONÔMICA APLICADAIPEA 2009).

The Brazilian wholesale price index ('IPA') was obtained from Conjuntura Econômica, a publication by Fundação Getúlio Vargas. The U.S. wholesale price index was obtained from the Institute of Applied Economic Research, originally provided by the Bureau of Labor Statistics (IPEA 2009, FUNDAÇÃO GETÚLIO VARGASFGV 2009).

Some data being unavailable and understanding that the obtained data will suffice for the intended purposes of the research, this study covered a relatively short time span and specific pulp and paper types.

\subsection{Shift-share method}

The method adopted was the shift-share model, a tool originally proposed by Curtis (1972) to analyze changes in employment and income patterns of rural economies in Alabama between 1960 and 1969. Changes were split into three effects: national growth, composition of economic activities and regional differences in economic activities.

The above method has been widely used in economics literature to explain changes in the composition of agricultural production, through decomposition of the following effects: (i) cultivated area, in turn split into scale and substitution effects; (ii) yield per hectare; (iii) geographic location; and (iv) crop structure. Studies by Almeida (2003), Curi (1997), Felipe \& Maximiano (2008), Igreja et al. (1983), Moreira (1996), Patrick (1975), Shikida \& Alves (2001), Souza \& Lima (2002) and Yokoyama (1988) adopted this model to evaluate sources of output growth by decomposing the above effects.

Patrick (1975) analyzed sources of growth for 23 Brazilian agricultural products in the period between 1948 and 1969. This analysis was also performed by Souza \& Lima (2002) on 19 crops between 1975 and 1995 in an attempt to identify changes in the Brazilian agricultural composition.

Igreja et al. (1983) quantified sources of growth in the agricultural sector of São Paulo state for the period between 1966 and 1977. Felipe \& Maximiano (2008) also conducted a study of sources of growth in agricultural output within São Paulo state for the period between 1990 and 2005.

Following the same procedure, a study by Yokoyama (1988) analyzed the evolution of the agricultural sector in Goiás state between 1975 and 1984, and Moreira (1996) assessed sources of growth in the agricultural sector of Rio Grande do Norte state between 1981 and 1992. Curi (1997) applied the same model to Minas Gerais state, while Shikida \& Alves (2001) applied the model to Paraná state between 1981 and 1998. Almeida (2003) studied sources of growth in rice crops of Mato Grosso state between 1980 and 1985.

The shift-share model can also be used to explain the effects of exchange rate variation on prices of agricultural products, by decomposing the total effect of price variation, as expressed in Brazilian currency, into the dollar effect which results from international price changes and the exchange rate effect which results from exchange rate changes, as discussed in the works of Reis \& Campos (1998) and Silva \& Carvalho (1995).

Studies of this kind being scarce and related literature failing to provide material with this model applied to forest products, and considering its importance, this

Cerne, Lavras, v. 16, n. 2, p. 137-144, abr./jun. 2010 
work aims to decompose variations in international price of pulp and paper as expressed in Brazilian currency into the two above effects, according to Reis \& Campos (1998) and Silva \& Carvalho (1995).

Both studies-Silva \& Carvalho (1995) and Reis \& Campos (1998) — considered that the price in Brazilian currency of a commodity traded in the external market is based on its dollar price and the nominal exchange rate adopted in Brazil. Yet, Silva \& Carvalho (1995) determined these effects considering a cross-sectional analysis while Reis \& Campos (1998) considered a time frame.

For the above authors, the price in Brazilian currency of a commodity traded in the external market is derived from its dollar price and the nominal exchange rate adopted in Brazil. According to Krugman \& Obstfeld (2005), nominal exchange rate refers to the relative price of two currencies, thus differing from real exchange rate in that the latter refers to the relative price of two market baskets of a commodity. Mathematically, real exchange rate can be expressed by equation (1):

$E=e \frac{P^{*}}{P}$

where $E$ is the real exchange rate; $e$ is the nominal exchange rate; $P *$ is the Brazilian market price index, known as 'IPA'; and $P$ refers to the external market price index, corresponding to U.S. 'IPA'.

Based on the above principle, the variation in paper and pulp price, expressed in reais, for a time interval $t$, is given by equation (2):

$P R_{t}=P D_{t} \cdot E_{t}$

where: $P R_{t}=$ paper and pulp price in Brazilian reais; $P D_{t}=$ paper and pulp price in U.S. dollars; and $E_{t}=$ real exchange rate of Brazil (R\$/US\$).

Similarly, to derive the variation in paper and pulp price in initial period $O\left(P R_{0}\right)$, one should consider the dollar price in that initial period $\left(P D_{0}\right)$ and the real exchange rate of Brazil referring to that initial period $\left(E_{0}\right)$.

Equation (3) expresses variation in paper and pulp price, in Brazilian reais, with only the dollar price fluctuating.

$$
P R_{t}^{P D}=P D_{t} \cdot E_{0}
$$

By contrast, when the exchange rate fluctuates, and other elements being constant, equation (4) is derived:
$P R_{t}^{E}=P D_{0} \cdot E_{t}$

To determine the variation in paper and pulp price, in Brazilian reais, between initial period 0 and period $t$, equation (5) is used:

$$
P R_{t}-P R_{0}=\left(P R_{t}^{P D}-P R_{0}\right)+\left(P R_{t}-P R_{t}^{P D}\right)
$$

Component $P R_{t}-P R_{0}$ indicates total variation in paper and pulp price, in reais, and breaks down into international price effect, in dollars, and exchange rate effect, respectively represented by the first and second terms to the right of equation (5).

According to Silva \& Carvalho (1995), the price effect isolates variations in the price of an agricultural product, expressed in reais, resulting from variations in its price in the external market, expressed in dollars, while the exchange rate effect follows the same line of reasoning only with exchange rate figures.

These effects can be expressed individually in the form of growth rates. Mathematical handling of equation (5) derives the average monthly rate of variation in paper and pulp price, in reais and in percentage terms, as given by equation (6):

$r=\left[\left(\frac{P R_{t}}{P R_{0}}\right)-1\right] .100$

Equation (6) corresponds to total effect, which is decomposed into international dollar price effect and exchange rate effect respectively, according to equation (7):

$$
r=\frac{\left(P R_{t}^{P D}-P R_{0}\right)}{\left(P R_{t}-P R_{0}\right)} \cdot r+\frac{\left(P R_{t}-P R_{t}^{P D}\right)}{\left(P R_{t}-P R_{0}\right)} \cdot r
$$

Initial period $O$ is assumed to be the same as period $t_{-1}$ for purposes of determining monthly rate between two periods.

To complement the analysis, the coefficient of variation $(\mathrm{CV})$ was calculated of pulp and paper prices in Brazilian currency, and of the exchange rate, in order to assess price instability throughout the period, as given by equation (8).

$$
C V_{x}=\left(\sigma_{x} / M E D_{x}\right) \cdot 100
$$


where: $\mathrm{CV}_{\mathrm{x}}=$ coefficient of variation of variable $\mathrm{x} ; \sigma_{\mathrm{x}}=$ standard deviation of variable $\mathrm{x} ; \mathrm{MED}_{\mathrm{x}}=$ mean of variable $\mathrm{x}$.

\section{RESULTS AND DISCUSSION}

Before analyzing dollar and exchange rate effects on pulp and paper prices in Brazil, one should look into the price pattern of these products during the relevant period, as well as the exchange rate, as illustrated in Figure 1.

It can be noted that while exchange rate and pulp prices in Brazilian currency fluctuated, international pulp prices increased from April 2003 to August 2008. As of September 2008, with the U.S. financial crisis, pulp prices dropped in Brazil and in the U.S., followed by an exchange rate drop.

The coefficient of variation $(\mathrm{CV})$ revealed a degree of instability in pulp prices in Brazilian currency $(\mathrm{CV}=10.34 \%)$. This variation resulted to a large degree from the exchange rate effect and to a lesser degree from the dollar effect, exchange rate showing greater variation $(\mathrm{CV}=17.78 \%)$ than dollar price $(\mathrm{CV}=15.24 \%)$.

As regards paper, from April 2003 to September 2008 the price behavior pattern was similar to pulp. From September 2008 to February 2009, however, paper prices in Brazilian currency and international prices started to show signs of recovery.

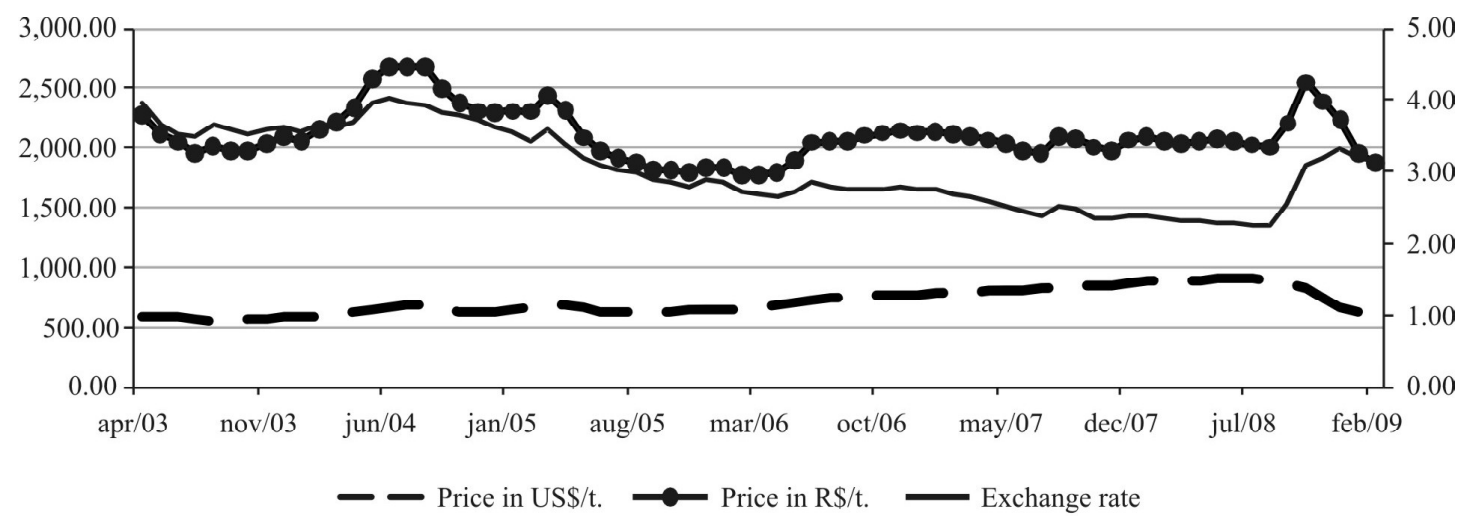

(a)

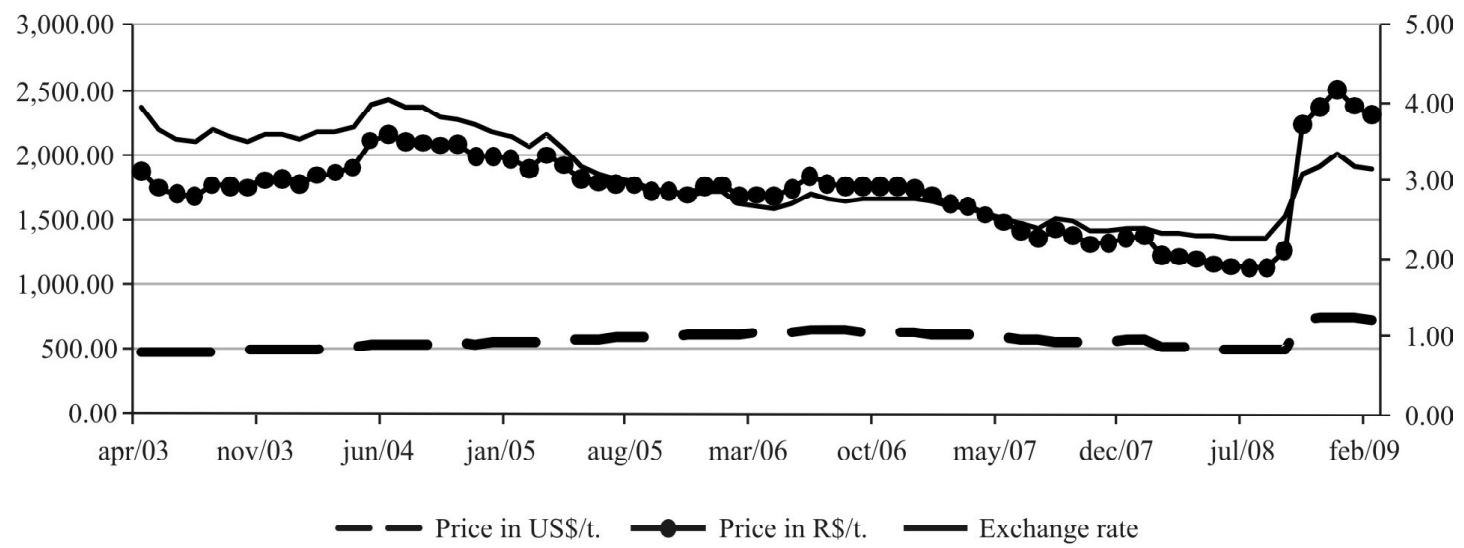

(b)

Source: FOEX as cited by Celulose Online (2009), and Central Bank of Brazil as cited by IPEA (2009).

Figure 1 - Nominal monthly prices of pulp (a) and paper (b) and average real exchange rate in Brazil between April 2003 and February 2009.

Figura 1 - Preços nominais mensais da celulose (a) e do papel (b) e taxa de câmbio real média do Brasil, abril de 2003 a fevereiro de 2009.

Cerne, Lavras, v. 16, n. 2, p. 137-144, abr./jun. 2010 
The coefficient of variation $(\mathrm{CV})$ revealed some instability also in paper prices in Brazilian currency $(\mathrm{CV}=18.26 \%)$. This variation resulted to a large degree from the exchange rate effect and to a lesser degree to the dollar effect, exchange rate showing greater variation $(\mathrm{CV}=17.78 \%)$ than dollar price $(\mathrm{CV}=11.86 \%)$.

Variations in exchange rate contributed to variability in pulp and paper prices in Brazilian currency. According to Silva \& Carvalho (1995), real exchange rate variation can equally increase or decrease price variability in Brazilian currency. Variability will be increased if, predominantly, at times when the currency is strong, prices in dollar are going down, and viceversa. If the reverse occurs, instability will be less noticeable, when prices on which to base calculations are in Brazilian currency.

Other than exchange rate variation, dollar price also explains price variation in Brazilian currency (Table 1).

Table 1 - Decomposition of monthly rate of increase in pulp and paper price, in Brazilian currency, from April 2003 to February 2009.

Tabela 1 - Decomposição da taxa mensal de crescimento do preço da celulose e do papel em moeda nacional, abril de 2003 a fevereiro de 2009.

\begin{tabular}{|c|c|c|c|c|c|c|}
\hline \multirow[b]{2}{*}{ Month } & \multicolumn{3}{|c|}{ Pulp } & \multicolumn{3}{|c|}{ Paper } \\
\hline & $\begin{array}{l}\text { Total } \\
\text { Effect }\end{array}$ & Dollar Effect & $\begin{array}{c}\text { Exchange Rate } \\
\text { Effect }\end{array}$ & $\begin{array}{l}\text { Total } \\
\text { Effect }\end{array}$ & Dollar Effect & $\begin{array}{c}\text { Exchange Rate } \\
\text { Effect }\end{array}$ \\
\hline Apr/03 & - & - & - & - & - & - \\
\hline May/03 & -6.757 & 0.757 & -7.514 & -6.70 & 0.82 & -7.52 \\
\hline Jun/03 & -3.432 & 0.000 & -3.432 & -2.75 & 0.70 & -3.46 \\
\hline $\mathrm{Jul} / 03$ & -4.624 & -3.614 & -1.010 & -1.03 & 0.02 & -1.05 \\
\hline Aug/03 & 3.086 & -1.685 & 4.771 & 5.14 & 0.27 & 4.87 \\
\hline Sep/03 & -2.077 & 0.069 & -2.146 & -0.33 & 1.86 & -2.18 \\
\hline Oct/03 & 0.174 & 2.033 & -1.859 & -0.71 & 1.13 & -1.84 \\
\hline Nov/03 & 3.335 & 1.356 & 1.979 & 3.16 & 1.18 & 1.98 \\
\hline Dec/03 & 2.639 & 1.920 & 0.720 & 0.34 & -0.36 & 0.70 \\
\hline $\mathrm{Jan} / 04$ & -1.824 & 0.040 & -1.864 & -1.76 & 0.10 & -1.87 \\
\hline $\mathrm{Feb} / 04$ & 4.563 & 1.617 & 2.945 & 3.57 & 0.65 & 2.92 \\
\hline Mar/04 & 3.358 & 3.597 & -0.240 & 0.99 & 1.22 & -0.23 \\
\hline Apr/04 & 5.069 & 3.748 & 1.321 & 2.28 & 1.00 & 1.29 \\
\hline May/04 & 10.273 & 2.346 & 7.927 & 10.83 & 2.87 & 7.97 \\
\hline Jun/04 & 4.055 & 2.294 & 1.762 & 2.22 & 0.49 & 1.73 \\
\hline $\mathrm{Jul} / 04$ & 0.213 & 2.487 & -2.274 & -2.53 & -0.32 & -2.21 \\
\hline Aug/04 & -0.373 & -0.041 & -0.331 & -0.36 & -0.03 & -0.33 \\
\hline Sep/04 & -6.474 & -3.478 & -2.996 & -1.17 & 2.00 & -3.17 \\
\hline Oct/04 & -4.806 & -4.020 & -0.786 & 0.64 & 1.47 & -0.83 \\
\hline Nov/04 & -3.050 & -1.339 & -1.710 & -4.82 & -3.14 & -1.68 \\
\hline Dec/04 & -0.597 & 2.032 & -2.630 & 0.41 & 3.07 & -2.66 \\
\hline $\mathrm{Jan} / 05$ & 0.598 & 2.328 & -1.730 & -1.42 & 0.27 & -1.70 \\
\hline $\mathrm{Feb} / 05$ & -0.131 & 3.571 & -3.702 & -3.35 & 0.24 & -3.58 \\
\hline
\end{tabular}

Continua...

To be continued...

Cerne, Lavras, v. 16, n. 2, p. 137-144, abr./jun. 2010 
Tabela 1 - Continua...

Table 1 - Continued...

\begin{tabular}{|c|c|c|c|c|c|c|}
\hline \multirow[b]{2}{*}{ Month } & \multicolumn{3}{|c|}{ Pulp } & \multicolumn{3}{|c|}{ Paper } \\
\hline & $\begin{array}{l}\text { Total } \\
\text { Effect }\end{array}$ & Dollar Effect & Exchange Rate Effect & $\begin{array}{l}\text { Total } \\
\text { Effect }\end{array}$ & Dollar Effect & $\begin{array}{c}\text { Exchange Rate } \\
\text { Effect }\end{array}$ \\
\hline Apr/05 & -5.094 & 0.068 & -5.162 & -3.94 & 1.28 & -5.22 \\
\hline May/05 & -9.839 & -3.491 & -6.348 & -5.76 & 0.88 & -6.64 \\
\hline Jun/05 & -5.725 & -3.360 & -2.365 & -1.12 & 1.36 & -2.48 \\
\hline $\mathrm{Jul} / 05$ & -2.986 & -0.667 & -2.319 & -0.50 & 1.88 & -2.38 \\
\hline Aug/05 & -1.640 & -0.498 & -1.141 & -0.54 & 0.61 & -1.15 \\
\hline Sep/05 & -3.680 & -0.531 & -3.149 & -2.61 & 0.57 & -3.18 \\
\hline Oct/05 & 0.108 & 1.415 & -1.307 & -0.41 & 0.89 & -1.30 \\
\hline Nov/05 & -1.291 & 1.075 & -2.367 & -1.48 & 0.88 & -2.36 \\
\hline Dec/05 & 2.810 & 0.131 & 2.678 & 3.75 & 1.05 & 2.70 \\
\hline $\mathrm{Jan} / 06$ & -0.268 & 0.005 & -0.272 & 0.79 & 1.07 & -0.28 \\
\hline $\mathrm{Feb} / 06$ & -3.246 & 1.905 & -5.151 & -4.68 & 0.40 & -5.07 \\
\hline Mar/06 & -0.302 & 1.198 & -1.499 & 0.34 & 1.85 & -1.51 \\
\hline Apr/06 & 1.147 & 2.729 & -1.582 & -0.95 & 0.60 & -1.55 \\
\hline May/06 & 5.648 & 2.611 & 3.037 & 3.63 & 0.65 & 2.98 \\
\hline Jun/06 & 8.223 & 3.328 & 4.896 & 5.35 & 0.58 & 4.77 \\
\hline $\mathrm{Jul} / 06$ & 0.442 & 3.040 & -2.598 & -2.78 & -0.26 & -2.51 \\
\hline Aug/06 & 0.009 & 1.184 & -1.175 & -1.22 & -0.06 & -1.16 \\
\hline Sep/06 & 2.406 & 1.716 & 0.690 & 0.26 & -0.42 & 0.68 \\
\hline Oct/06 & 1.022 & 0.944 & 0.077 & -0.28 & -0.36 & 0.08 \\
\hline Nov/06 & 1.021 & 0.060 & 0.961 & 0.09 & -0.87 & 0.95 \\
\hline Dec/06 & -0.889 & 0.000 & -0.889 & -1.25 & -0.37 & -0.89 \\
\hline Jan/07 & 0.406 & 1.310 & -0.905 & -2.44 & -1.56 & -0.88 \\
\hline $\mathrm{Feb} / 07$ & -0.873 & 1.268 & -2.141 & -3.84 & -1.76 & -2.08 \\
\hline Mar/07 & -0.730 & 0.003 & -0.733 & -1.35 & -0.63 & -0.73 \\
\hline Apr/07 & -1.730 & 1.308 & -3.038 & -4.17 & -1.20 & -2.96 \\
\hline May/07 & -1.696 & 1.092 & -2.789 & -3.98 & -1.26 & -2.72 \\
\hline Jun/07 & -2.715 & 0.115 & -2.830 & -4.63 & -1.85 & -2.77 \\
\hline $\mathrm{Jul} / 07$ & -0.904 & 1.535 & -2.439 & -3.88 & -1.52 & -2.37 \\
\hline Aug/07 & 6.984 & 0.913 & 6.071 & 4.84 & -1.11 & 5.95 \\
\hline Sep/07 & -0.884 & 1.157 & -2.041 & -3.11 & -1.11 & -1.99 \\
\hline Oct/07 & -3.281 & 1.118 & -4.400 & -4.69 & -0.36 & -4.34 \\
\hline Nov/07 & -1.358 & -0.799 & -0.559 & 0.17 & 0.74 & -0.57 \\
\hline
\end{tabular}

Continua...

To be continued...

Cerne, Lavras, v. 16, n. 2, p. 137-144, abr./jun. 2010 
Tabela 1 - Continua...

Table 1 - Continued...

\begin{tabular}{lcccccc}
\hline & \multicolumn{3}{c}{ Pulp } & & \multicolumn{2}{c}{ Paper } \\
\cline { 2 - 7 } Month & Total & Dollar Effect & Exchange Rate Effect & $\begin{array}{c}\text { Total } \\
\text { Effect }\end{array}$ & Dollar Effect & $\begin{array}{c}\text { Exchange Rate } \\
\text { Effect }\end{array}$ \\
\hline Effect & 4.143 & 1.991 & 2.152 & 3.04 & 0.91 & 2.13 \\
Jan/08 & 1.594 & 2.156 & -0.562 & 1.23 & 1.79 & -0.56 \\
Feb/08 & -1.844 & 0.292 & -2.136 & -10.74 & -8.80 & -1.94 \\
Mar/08 & -0.812 & 0.000 & -0.812 & -0.93 & -0.12 & -0.81 \\
Apr/08 & 0.653 & 1.191 & -0.538 & -1.46 & -0.93 & -0.53 \\
May/08 & 1.189 & 1.559 & -0.370 & -3.19 & -2.84 & -0.35 \\
Jun/08 & -1.100 & -0.066 & -1.034 & -1.43 & -0.40 & -1.03 \\
Jul/08 & -1.565 & -0.607 & -0.957 & -1.04 & -0.07 & -0.96 \\
Aug/08 & -0.809 & -1.169 & 0.360 & 0.12 & -0.24 & 0.36 \\
Sep/08 & 9.864 & -2.097 & 11.961 & 12.02 & -0.17 & 12.20 \\
Oct/08 & 15.728 & -5.004 & 20.732 & 76.76 & 45.09 & 31.67 \\
Nov/08 & -6.367 & -9.567 & 3.200 & 5.94 & 2.32 & 3.62 \\
Dec/08 & -6.383 & -10.142 & 3.759 & 5.83 & 1.58 & 4.25 \\
Jan/09 & -12.371 & -8.008 & -4.363 & -5.16 & -0.44 & -4.72 \\
Feb/09 & -4.606 & -4.321 & -0.285 & -2.51 & -2.22 & -0.29 \\
\hline Source: Renyyyyyyyyyyyyy
\end{tabular}

Source: Research Data.

Variations were noted in international prices of pulp and paper, in Brazilian currency, when monthly rates of increase were calculated (total effect). Greater variation in pulp price was noted in October 2008, when the monthly rate of increase reached $15.728 \%$, relative to September 2008. This price increase in Brazilian currency was influenced mainly by the exchange rate (exchange rate effect), which fluctuated by about $20.732 \%$, followed by a $-5.004 \%$ variation in the dollar price (dollar effect). Then a drop followed in the monthly rate of increase in pulp price in Brazilian currency after this period. Slighter variation in the rate of increase in pulp prices was noted in August 2006, at $0.009 \%$. This rate consists of the sum of dollar effect, at $1.184 \%$, and exchange rate effect, at $-1.175 \%$.

As for paper, greater variation in price was noted also in October 2008, when the monthly rate of increase reached $76.76 \%$, relative to September the same year. The increase in dollar price (dollar effect), which fluctuated by about $45.09 \%$, was the main contributing factor to the increase in paper price in Brazilian currency, followed by a $31.67 \%$ variation in the exchange rate (exchange rate effect). Slighter variation was noted in November 2006, at $0.09 \%$.
This rate consists of the sum of dollar effect, at $-0.87 \%$, and exchange rate effect, at $0.95 \%$ (Table 1 ).

The exchange rate effect was noted to prevail in this study, the dollar effect being relatively slighter in the breakdown of pulp and paper prices, in Brazilian currency. Yet, in the case of pulp, the negative dollar effect from November 2008 to February 2009 had great significance, overriding the exchange rate effect. In these periods, the positive dollar effect caused prices in Brazilian currency to show great negative variations. In the case of paper, the positive dollar effect in October 2008 overrode the exchange rate effect, causing paper prices to show greater positive variations.

According to Silva \& Carvalho (1995), real exchange rate variations exert considerable impact on the external competitiveness of an export. In the specific case of pulp and paper, real exchange rate variations can be compounded by the effects of incentives to exports and production in other countries, with implications for the Brazilian pulp and paper sector regarding external competitiveness (GARCIA 2002, SIQUEIRA 2002). Inherently, competitiveness depends on factors other than price alone, yet price is an important component.

Cerne, Lavras, v. 16, n. 2, p. 137-144, abr./jun. 2010 


\section{CONCLUSIONS}

From obtained results it can be inferred that the behavior pattern of pulp and paper price in Brazilian currency differed from that in U.S. dollar, for the period in question. This fact indicates that dollar prices had less influence on prices in Brazilian real than the exchange rates adopted over the period in question.

The intensity of the exchange rate effect on variability in pulp and paper prices in Brazilian currency was conditional on the intensity of dollar price variations, indicating that variations in exchange rate can reduce, invalidate or potentiate the effect of dollar price variations. This indicates that adopting an exchange rate that makes the national currency stronger could lead to harmful consequences for the Brazilian pulp and paper sector, possibly aggravating the crisis currently faced by the sector.

\section{ACKNOWLEDGMENTS}

We wish to thank the National Council for Scientific and Technological Development (CNPq) and the Federal University of Viçosa.

\section{BIBLIOGRAPHICAL REFERENCES}

ALMEIDA, P. N. A. Fontes de crescimento e sistema produtivo da orizicultura no Mato Grosso. 2003. 213 p. Dissertação (Mestrado em Ciências) - Universidade de São Paulo, São Paulo, 2003.

ASSOCIAÇÃO BRASILEIRA DE CELULOSE E PAPE. Setor de celulose e papel. 2008. Disponível em: <http:// www.bracelpa.org.br/\$. Acesso em: 22 mar. 2009.

CELUlose ONLINE. Cotações de C\&P. Disponível em:

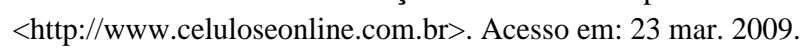

CURI, W. F. Eficiência e fontes de crescimento da agricultura mineira na dinâmica de ajustamentos da economia brasileira. 1997. 182 f. Tese (Doutorado em Economia Rural) Universidade Federal de Viçosa, Viçosa, 1997.

CURTIS, W. C. Shift-share analysis as a technique in rural development research. American Journal of Agricultural Economics, Saint Paul, v. 54, n. 2, p. 267-70, May 1972.

FELIPE, F. I.; MAXIMIANO, M. L. Dinâmica da agricultura no Estado de São Paulo entre 1990-2005: uma análise através do modelo "shift share". In: CONGRESSO BRASILEIRO DE
ECONOMIA E SOCIOLOGIA RURAL, 46., 2008, Rio Branco. Anais... Rio Branco: SOBER, 2008. CD-ROM.

FOOD AND AGRICULTURE ORGANIZATION. Disponível em: <http// iwww.fao.orgy. Acesso em: 23 abr. 2009.

FUNDAÇÃO GETÚLIO VARGAS. Indicadores e estatísticas: conjuntura econômica. Rio de Janeiro, 2009.

GARCIA, J. D. P. Perspectivas estruturais da comercialização de produtos florestais. Brasília: Ministério do Meio Ambiente, 2002. $71 \mathrm{p}$.

IGREJA, A. C. M.; CARMO, M. S.; GALVÃO, C. A.; PELLEGRINI, R. M. P. Análise quantitativa do desempenho da agricultura paulista, 1966-1977. Agricultura em São Paulo, São Paulo, v. 30, n. 1/2, p. 117-157, 1983.

INSTITUTO DE PESQUISA ECONÔMICA APLICADA.

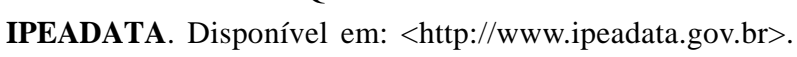
Acesso em: 20 mar. 2009.

KRUGMAN, P. R.; OBSTFELD, M. Economia Internacional: teoria e política. São Paulo: Pearson Addison Wesley, 2005. 558 p.

MOREIRA, C. G. Fontes de crescimento das principais culturas do Rio Grande do Norte 1981-1992. 1996. 109 p. Dissertação (Mestrado em Ciências) - Universidade de São Paulo, São Paulo, 1996.

PATRICK, G. F. Fontes de crescimento da agricultura brasileira: o setor de culturas. In: CONTADOR, C. R. Tecnologia e desenvolvimento agrícola. Rio de Janeiro: IPEA/INPES, 1975. p. 89-110. (Série Monográfica, 17).

REIS, S. M.; CAMPOS, R. T. Efeitos da taxa de câmbio sobre os preços do cacau. In: CONGRESSO BRASILEIRO DE ECONOMIA E SOCIOLOGIA RURAL, 36., 1998, Poços de Caldas. Anais... Poços de Caldas: SOBER, 1998. v. 2, p. 89100.

SHIKIDA, P. F. A.; ALVES, L. R. A. Panorama estrutural, dinâmica de crescimento e estratégias tecnológicas da agroindústria canavieira paranaense. Nova Economia, Belo Horizonte, v. 11, n. 2, p. 123-149, dez. 2001. 